\title{
Construction and Analysis of Chinese College Students' Entrepreneurship Motivation Model
}

\author{
Xiaofeng Ran ${ }^{1}$ Jinli Shi ${ }^{2, *}$ \\ ${ }^{1}$ School of Tourism Sciences, Beijing International Studies University, Beijing 100024, China \\ ${ }^{2}$ Teaching Affairs Office, Capital University of Physical Education and Sports, Beijing 100191, China \\ *Corresponding author. Email: shijinli@cupes.edu.cn
}

\begin{abstract}
With the rapid development of the economy, the pressure on Chinese job seekers has increased yearly. Facing the increasingly severe job market, more and more college students choose to start a business. Many colleges and universities offer courses to guide students in entrepreneurship, but most of these courses teach only theory and students have little opportunity to practice. In addition, these courses also ignore the motivation of college students to start a business, so that they cannot really meet the psychological needs of students. The entrepreneurial behavior of college students consists of a series of activities. By studying the motivation of college students to start a business, to understand the motivation of college students to start a business, we can predict and control the entrepreneurial behavior of college students, and then stimulate the entrepreneurial motivation of college students, improve their entrepreneurial ability. It could be helpful to improve the entrepreneurial efficiency of college students and enthusiasm for entrepreneurship.
\end{abstract}

Keywords: entrepreneurial motivation, model, college education, entrepreneurialship, variance analysis

\section{INTRODUCTION}

With the rapid development of China's economy and the increasingly difficult employment situation, many college students have joined the ranks of entrepreneurs. In China, some policies give support to college students for starting a business, but they still face ever-increasing obstacles during the start-up period. Thus, they will encounter bumps when starting their own business. In addition to national policies, some policies may influence college students' entrepreneurial motivation. Therefore, it is necessary to construct a model of college students' entrepreneurial. Exploring college students' entrepreneurial motivation and building relevant theoretical models to carry out multi-dimensional analysis is of great significance to start their own businesses successfully.

\section{RELATED WORK}

As early as the middle of the 18th century, research on entrepreneurial phenomena has begun in foreign countries. However, the academic community has never reached a consensus on the definition of the concept of entrepreneurship. Gartner defined entrepreneurship as the process by which new organizations are created [1]. Shane believed that entrepreneurship is to create new products through insight and utilization of favorable opportunities [2]. Thompson defined that entrepreneurship is the process of discovering and seizing opportunities, thereby creating novel products or services and realizing their potential value [3]. These definitions have a central idea that entrepreneurship is the process of integrating resources to create value.

In the analysis of entrepreneurial motivation and its influencing factors, there were disputes among scholars, and entrepreneurial activities have gradually become active among the general public in recent years. As entrepreneurship continues to grow popular, more scholars have turned their research focus on entrepreneurial motivation and its influencing factors. However, in different eras, the entrepreneurial policies and entrepreneurial environments with which researchers were exposed are not the same. Besides, various research places and research objects will also bring about contrasts in research results. Bosserman and Olson pointed out that entrepreneurial motivation is the driving force behind entrepreneurial behavior [4]. These driving forces encourage individuals with entrepreneurial ability and entrepreneurial conditions to start a business, and are also an essential distinction between entrepreneurs and potential entrepreneurs; Smith, Baum, and Locke believed that entrepreneurial motivation is an internal driving force formed in the mind of entrepreneurs in the pursuit of achievement, with two indicators of goal orientation and selfefficacy. There were two types of empirical research on entrepreneurial motivation. One is the development and study of measuring tools for entrepreneurial motivation 
[5]. Based on theoretical construction, Hornsby, Naffziger and Kuratko proposed a four-factor structural model of entrepreneurial motivation through empirical research: external incentives (money and shares), internal incentives (internal control needs and achievement needs), independence, self-control, and family security (entrepreneurs provide life security for themselves and their families through entrepreneurship) [6]. Roger, Egbert, and Robichaud adopted empirical research to test the above four-factor structure [7]. They added some items, such as retirement preparation and life improvement, to develop a measurement tool for entrepreneurial motivation. The other category is a comparative study of entrepreneurial motivations. Through a comparative study of entrepreneurship between Silicon Valley and Japanese high-tech startups, Kim found that in terms of entrepreneurial motivation, Japanese entrepreneurs are more socialoriented, namely, seeking social recognition. While Silicon Valley entrepreneurs are more individualoriented, namely, what they are after is individual's sense of accomplishment and accumulation of wealth [8]. By comparing the entrepreneurial motivations of entrepreneurial CEOs and professional CEOs, Papalexandris and Galanaki found significant differences in entrepreneurial motivations between the two elements [9]. However, the existing literature did not propose the establishment of a mature theoretical framework for the entrepreneurial action of college students, which is not conducive to the selection, evaluation, and cultivation of entrepreneurship for college students.

\section{METHODOLOGY}

\section{A. Measuring tools}

The external cause of entrepreneurship motivation of Chinese college students is similar to the external environment found in the study of western entrepreneurship motivation. While the external environment referred to in the western study mainly refers to the macroeconomic environment and the government's preferential policies, not involving the impact of the entrepreneurial atmosphere and support on the entrepreneurial motivation of the school. In addition, the element of family impact is quite different from that of western studies. Although some western scholars have found that entrepreneurial parents can effectively stimulate their children's entrepreneurial motivation, but the entrepreneurship motivation scale has not included this dimension.

Thus, in the academic world, there is a lack of mature college students 'entrepreneurial motivation evaluation questionnaires for reference. In this study, the inductive method is adopted to construct the content dimensions of college students' entrepreneurial motivations, and based on this idea, a "university entrepreneurial motivation measurement questionnaire" was compiled. After a series of work such as in-depth interviews, open questionnaires, expert classification, and reliability tests, two aspects of college students entrepreneurial motivation, four content dimensions, and 16 typical behavior descriptions were obtained, as shown in the following "Table I".

TABLE I. CLASSIFICATION OF COLLEGE STUDENTS' ENTREPRENEURIAL MOTIVATION AND BEHAVIOR DESCRIPTION

\begin{tabular}{|l|l|l|l|}
\hline \multicolumn{2}{|c|}{ Internal factors } & \multicolumn{2}{l|}{ External factors } \\
\hline Fame and fortune & Self-realization & Marco policy & Family influence \\
\hline $\begin{array}{l}\text { Worship of } \\
\text { entrepreneurial idol }\end{array}$ & Realization of own value & $\begin{array}{l}\text { Preferential policies provided by the } \\
\text { state }\end{array}$ & Family and friend encouragement \\
\hline $\begin{array}{l}\text { To improve social } \\
\text { status }\end{array}$ & Proof of own talent & $\begin{array}{l}\text { Active support from local } \\
\text { governments }\end{array}$ & $\begin{array}{l}\text { Friends and family invited to start } \\
\text { a partnership }\end{array}$ \\
\hline To become wealthy & $\begin{array}{l}\text { Improvement of one's individual } \\
\text { quality }\end{array}$ & $\begin{array}{l}\text { Training courses offered by the } \\
\text { college }\end{array}$ & $\begin{array}{l}\text { Someone of family and friends has } \\
\text { started a successful business }\end{array}$ \\
\hline $\begin{array}{l}\text { Envy of rights and } \\
\text { status }\end{array}$ & Play of one's strengths & $\begin{array}{l}\text { Strong campus entrepreneurial } \\
\text { atmosphere }\end{array}$ & Family help \\
\hline
\end{tabular}

\section{B. Data collection}

The formal survey was launched from April to July 2019. The study was selected from undergraduates at universities in north China, mainly juniors and seniors. A total of 1,200 questionnaires were distributed, and 1,015 questionnaires were recovered, with a recovery rate of $84.58 \%$. After screening out invalid questionnaires, there were 903 valid questionnaires, with the active recovery rate was $75.25 \%$. Among the valid questionnaires, 538 were males, accounting for $59.6 \%$, and 365 were females, $40.4 \%$. From a professional background, 234 were in science and engineering, accounting for $25.91 \%, 514$ were in economics and management, accounting for $56.92 \%$, and 134 were in literature, history, and philosophy, accounting for $14.84 \%$ and 21 in other majors, accounting for $2.33 \%$. From the point of view of family background, students from villages and towns accounting for $37.8 \%, 28.1 \%$ from county towns and $34.1 \%$ from large and medium-sized cities. 


\section{ANALYSIS AND FINDINGS}

\section{A. Analysis of the factors of entrepreneurial motivation}

Factor analysis is one of the multivariate statistical techniques, which can transform some difficult and interrelated variables into several meaningful independent factors. The data were analyzed by SPSS19.0 software, and principal component analysis was adopted. Elements with characteristic roots more significant than 1 were extracted by orthogonal rotation, and the four-factor structure of entrepreneurial motivation was obtained.

From the results of exploratory factor analysis, college students' entrepreneurial motivation presents a four-factor structure. There are four projects for factor F1, including worship of entrepreneurial idols, to improve social status, to get rich for wealth, rights and status. Its content shows that the factor F1 is to meet an inherent psychological need, that is, the desire to have power, improve situation and obtain wealth, to gain respect and admiration from others, is an intrinsic driving factor. Therefore, the factor F1 is named "Fame and Fortune". There are four items in factor F2: realizing one's life value, showing one's talent, improving one's accomplishment, and exerting one's strengths. Its content shows that the connotation of factor F2 is to maximize the potential of one's own potential and continuously improve himself, so as to realize his ideal and prove his value. Therefore, the factor F2 is named "self-realization." There are four items in factor F3: Family and friends support for starting a business, family and friends invite partnerships to start a business, some family and friends have successfully started a business, and families help. According to the contents of items, it can be seen that factor F3 is that family members, relatives and friends actively encourage entrepreneurship, and can provide corresponding resources and conditions, which are external pulling factors. Therefore, factor F3 is named "Family Influence". There are four items in factor F4: preferential policies provided by the state, active support from local governments, training courses offered by schools, and a robust entrepreneurial atmosphere in schools. The items show that factor F4 refers to schools and governments actively encouraging entrepreneurship and providing corresponding resources and preferential conditions, which are external pulling factors. Therefore, the factor F4 is named "macro-policy".

As can be seen from "Table II", the most important reason for college students' entrepreneurial motivation is the need for self-realization, followed by family influence. Apart from the almost no correlation between social support and the pursuit of wealth, there is a clear weak correlation between other factors, especially the coefficients of correlation between social support and family influence. On the other hand, the correlation coefficient between self-realization and pursuit of wealth is weak as sell. Thus, it can be initially verified that the motivation of entrepreneurship is composed of internal psychological needs and external environmental support.

TABLE II. DESCRIPTION OF THE STRUCTURE OF COLLEGE STUDENTS' MOTIVATION TO START A BUSINESS (N=903)

\begin{tabular}{|l|l|l|l|l|l|}
\hline \multicolumn{7}{|c|}{ Structure } \\
\hline Factor & Mean & Variance & 1 & 2 & 3 \\
\hline F1 & 10.817 & 3.137 & & & \\
\hline F2 & 15.091 & 2.913 & $0.218^{* *}$ & & \\
\hline F3 & 12.187 & 2.971 & $0.108^{* *}$ & $0.157^{* *}$ & \\
\hline F4 & 10.801 & 3.191 & 0.005 & $0.153^{* *}$ & $0.423^{* *}$ \\
\hline
\end{tabular}

\section{B. Correlation analysis of entrepreneurial motivation and population variables}

1) Gender and entrepreneurial motivation: Many studies have shown that there are vast differences between different genders. In this study, the independent t-test was adopted to explore whether there are differences in the entrepreneurial motivations of college students of different genders, and what are the differences. The results are shown in "Table III". As can be seen from "Table III", there are significant differences between male and female college students in pursuit of fame and wealth and social support. At the same time, there are no remarkable differences in selfrealization and family influence. Male college students pay more attention to the pursuit of fame and fame than female college students, which means that men attach importance to their social status, honor and rights. These phenomena are related to the role of men in society. In general, possession of rights, state, and wealth are concrete manifestations of male success. In contrast, women are more willing to focus on family construction, and their desire for power and fame is relatively low. Male college students receive less social support than female college students when starting a business, which implies that male entrepreneurs want to 
rely on and believe in their abilities. Once they decide to start a business, they will do it without considering other conditions. And women may consider more factors, and wait until all requirements are mature before starting to act, so the risk is smaller. This difference reflects the influence of gender on college students' entrepreneurial motivation to start a business.

TABLE III. COMPARISON OF THE MOTIVATION OF COLLEGE STUDENTS OF DIFFERENT GENDERS

\begin{tabular}{|l|c|l|c|}
\hline Factor & t & Degree of freedom & Sig \\
\hline F1 & 5.314 & 903 & 0.000 \\
\hline F2 & -0.485 & 903 & 0.597 \\
\hline F3 & -1.577 & 903 & 0.075 \\
\hline F4 & -2.896 & 903 & 0.005 \\
\hline
\end{tabular}

2) Professional background and entrepreneurial motivation: College students with different professional backgrounds have quite different behavioral different patterns of behavior and thinking. In this study, we intended to adopt a variance analysis to examine the distinction in entrepreneurial motivation among college students with different majors. College students from diverse professional backgrounds have significant differences in self-realization and social support. At the same time, there is no significant difference in pursuit wealth and family influence. College students of science and engineering are superior to college students of financial management in terms of self-realization. Financial management college students are significantly excellent to other majors in social support. Financial management courses are more about teaching college students how to integrate external resources for their use in order to achieve "maximum utilization of resources", which can be proven by the results. Students of this kind of professional always have a strong sense of opportunity and are good at grasping them. When the external conditions are mature, even if they have not thought about creating a business of their own, they may also choose to start a business because of the temptation of resources and conditions. Students from other majors, however, pay more attention to reality and are more willing to control and utilize the resources they already have.

3) Family background and entrepreneurial motivation: There are great differences between rural and urban college students' growth environment. This study aims to explore the backs of different families through the variance analysis. The results show that there are significant differences in self-realization among college students from different family backgrounds, and there are no significant differences in the pursuit of fame and wealth, family influence and social support. The self-realization degree of college students in villages and towns is higher than that of college students in large and medium-sized cities. This may be caused by different growth environments between college students in villages and cities and college students.

\section{CONCLUSION}

\section{A. Discussion}

In this study, with the help of 903 questionnaire surveys of college entrepreneurs, the dimensions and structure of college students' entrepreneurial motivation were thoroughly explored by using exploratory factor analysis, association analysis of entrepreneurial motivation, and demographic variables. The research results in the article show that college students' social entrepreneurial motivations show a four-dimensional structural model. Internal motivation includes the two dimensions of fame and fortune pursuit and selfactualization; External motivation consists of two aspects: macro policy and household influence. Among motivating college students' entrepreneurial motivation, in addition to their psychological needs, the impact of the external environment is also an essential condition that cannot be ignored. The questionnaire designed in this study meets the requirements of psychometrics, and the results of it can be adopted for the selection and training of entrepreneurial talents. There are obvious differences in the structure of entrepreneurial motivation among college students of different genders and majors.

In the study, from the analysis of factors, the structure of the factors is clear and the distribution of the project is balanced. Also, the load value of each project factor is high. Both the cumulative variance interpretation rate of the factors and the alpha coefficient meet the requirements of psychometrics. Therefore, it can be concluded that the degree of reliability and validity of the scale of entrepreneurship motivation of college students obtained by this research institute is high, and the structure is scientific and reasonable. The emergence of college students' motivation for entrepreneurship is the comprehensive result of internal psychological demand and external environment.

\section{B. Assessment of the research}

As an exploratory study, the limitations of this study were also recognized by the author. First, the boundaries of the sampling method and the number of samples collected in this study have not met the requirements of extensive sample surveys, which may affect the robustness of the research results. Also, due 
to the limitations of cross-section data, in future research, time-series data and extensive sample studies are needed to bring the conclusion closer to the origin of college students' entrepreneurial motivation. Second, in this study, the five-point scale personal evaluation method was used to measure the college students' entrepreneurial motivation scales. Although this method of subjective evaluation is generally accepted and recognized in behavioral science, the results will be affected by the social expectation effect to some extent. When asked about options that are consistent with the general expectations of the society, the respondents' responses generally align with the social expectations, and cannot truly reflect their original motivations and ideas. Therefore, in future research, objective measurement items need to be considered as much as possible. Finally, this study is only a preliminary consideration of the measurement model for the social entrepreneurial motivation structure of college students. Therefore, extensive empirical research is needed to continuously optimize the design of this measurement scale, so as provide a basis for quantitative analysis for further exploring the relationship between social entrepreneurial motivation and complex causal variables, and truly explore the causal relationship between factors.

\section{References}

[1] A.Gartner, Conceptual Framework for Describing the Phenomenon of New Venture Creation. Academy of Management Review. 10(4). pp. 696-706.

[2] V.Shane, The promise of Entrepreneurships a Field of Research. Academy of Management Review. 25(1). pp.217-226.

[3] J.L.Thompson, The world of the Social Entrepreneur.The International

[4] Joumal of Public Sector Management, 2002(15). Pp.412-431.

[5] P. Olsen, and D. Bosserman, Attributes of the Entrepreneurial Type. Business Horizons, 1984. pp53-56.

[6] K.G.Smith, J.R.Baum, and E.A. Locke, A Multidimensional Model of Venture. Academy of Management Journa. 2001(44), pp.292-303.

[7] J. S.Hornsby, D. W.Naffziger, and D. F. Kuratko, An Examination of Owner' Goals in Sustaining Entrepreneurship. Journal of Small Business Management.35(1), pp.24-33.

[8] A. Roger, M. Egbert, and Y. Robichaud, Toward the Development of a Measuring Instrument for Entrepreneurial Motivation. Journal of Developmental Entrepreneurship. 6(2). Pp.189-201.

[9] Z.T.Bae, S.H.Kim, and K. I. Suzuki, Entrepreneurship in Japan and Silicon Valley: A Comparative Study. Technovation, 2002.

[10] N. Papalexandris,and E.Galanaki , Entrepreneurial and Professional CEOs: Differencesin Motive and Responsibility Profile. Leadership \& Organization Development Journal.26(2).pp.141-162. 